\title{
INSTYTUCJONALNY, SPOŁECZNY I POLITYCZNY WYMIAR PRETORIANIZMU TURECKIEGO
}

\author{
Maciej Herbut* \\ INSTITUTIONAL, SOCIAL AND POLITICAL ASPECTS \\ OF TURKISH PRAETORIANISM
}

\begin{abstract}
The term 'praetorianism' refers to countries in which the armed forces influence the political system. The army, as an institution, can develop its political power in two ways: in a "direct" and "indirect" fashion. While in the first case the armed forces take control over state institutions, the second is more sublime and is restricted to the building of more concealed methods of influence, such as blackmail. Additionally, the army itself, as the officers are not engaged into politics, shows a high level of political cohesion and military professionalism. Turkey is an example of a country in which a professional army, after decades of acquiring political experience and under favourable conditions, was and still is able to efficiently exert backstage politics. On one side, TSK (Turkish Armed Forces) has developed constitutional and legal means of influencing the government, and on the other, the high public trust in the armed forces allows it to, if necessary, effectively blackmail or even supplant disobedient cabinets.
\end{abstract}

\section{KEYWORDS}

civil-military relations, praetorianism, Turkey, authoritarianism, military

* Uniwersytet Wrocławski, Instytut Politologii. 
Pretorianizm to kategoria dotycząca relacji cywilno-wojskowych, w których wojsko przejawia chęć przejęcia kontroli nad instytucjami państwowymi lub też wywierania na nie wpływu. Większość autorów zgadza się więc z tezą, iż pretorianizacja państwa to pewien rodzaj patologii życia publicznego i politycznego, który nie tylko prowadzi do osłabiania instytucji państwa, ale także do upadku wartości moralnych zarówno elit, jak i społeczeństwa ${ }^{1}$. Odwołując się do różnych definicji pretorianizmu, nie sposób nie dostrzec, że poziom profesjonalizacji armii z reguły ma bezpośrednie przełożenie na charakter oraz sposoby ingerowania korpusu oficerskiego w życie polityczne państwa. Armie, które cechuje wysoki poziomie upolitycznienia, niski poziom profesjonalizmu i doświadczenia politycznego, często wykorzystują instrumenty bezpośredniej kontroli nad instytucjami publicznymi ${ }^{2}$. Natomiast armie, które cechuje wysoki poziom profesjonalizmu, dążą raczej do ukrycia swojego wpływu politycznego i do stworzenia bardziej „wysublimowanych” sposobów kontroli politycznej33. Podczas gdy działania tych pierwszych często prowadzą do pojawienia się podziałów wewnątrz samego korpusu oficerskiego, przewrotów politycznych, a nawet wojen domowych, to w państwach dotkniętych drugą formą pretorianizmu dochodzi raczej do stabilizacji sytuacji politycznej. Metody wywierania wpływu pośredniego przez armie gwarantują więc oficerom bardziej efektywne i długotrwałe oddziaływanie na instytucje publiczne, co powoduje, że armia silnie „zakorzenia” się w systemie politycznym. Celem opracowania jest ukazania teoretycznych aspektów pretorianizmu, a także przedstawienie mechanizmów działania armii pretoriańskiej na przykładzie doświadczeń tureckich. Mając na uwadze, że relacje cywilno-wojskowe w Turcji, poczynając od reform Atatürka do dnia dzisiejszego, podlegały ciągłej ewolucji, nie sposób nie dostrzec, że także pozycja armii ulegała ciągłym zmianom. Co więcej, oprócz sformalizowanych form nacisku na elity polityczne, które mają swoje oparcie w aktach prawnych oraz w ustawie zasadniczej, armie pretoriańskie stosują także mniej sformalizowane metody wywierania wpływu politycznego. Skuteczność wywierania przez armie wpływu na najważniejsze decyzje w państwie day-to-day politics znacznie

1 D.C. Rapoport, A Comparative Theory Of Military and Political Types, [w:] Changing Patterns Of Military Politics, red. S.P.Huntington, New York 1962, s. 72; S.P. Huntington, Political Order in Changing Societies, Yale 1974, s. 192-264.

2 Zob. P.J. Schraeder, African Politics and Society; a Mosaic of Transormation, Boston 2000, s. 247; W. Tardoff, Government and Politics in Africa, London 1997, s. 197.

3 S. Cook, Ruling not Governing, the Military and Political Development in Egypt, Algeria and Turkey, Baltimore 2007. 
jednak wzrasta, jeżeli jej pozycja jest mocniej osadzona w istniejącym porządku instytucjonalno-prawnym. Ponieważ celem pracy jest ukazanie źródeł oraz procesów kształtowania mechanizmów służących wzmocnieniu pretorianizmu tureckiego, a nie jego erozji, która zaczęła następować wraz z przejęciem władzy przez Partię Sprawiedliwości i Rozwoju (Adalet ve Kalkınma Partisi - AKP), relacje pomiędzy armią a partią rządzącą nie zostaną rozwinięte w niniejszym opracowaniu.

\section{PRETORIANIZM JAKO PRZEJAW SIŁY POLITYCZNEJ ARMII}

Klasyczne teorie pretorianizmu (S.P. Huntingtona i D.C. Rapoporta) odnoszą się $\mathrm{z}$ reguły do państw, w których procesowi degeneracji pierwotnych funkcji armii (upolitycznienie i spadek skuteczności bojowej) towarzyszą korupcja i paraliż instytucji państwa ${ }^{4}$. Warto jednak zwrócić uwagę na koncepcję A. Paerlmuttera, która nieco odbiega od tych proponowanych przez wspomnianych wcześniej autorów. Podczas gdy Huntington i Rapoport dopatrują się słabości armii jako źródła degradacji instytucji publicznych i życia politycznego, zdaniem Perlmuttera to nie w armii, lecz w skorumpowanym systemie politycznym należałoby doszukiwać się źródeł słabości państwa ${ }^{5}$. Co więcej, jeżeli armia będzie profesjonalna, zdyscyplinowana, to jej ingerencja w życie polityczne może okazać się czynnikiem stabilizującym, a nie pogłębiającym chaos w państwie. Opinię tę wydaje się popierać Morris Janovitz, który zwraca uwagę, że na przełomie lat sześćdziesiątych i siedemdziesiątych dwudziestego wieku, część państw dotkniętych pretorianizmem, jak np. Egipt czy Turcja, staje się bardziej stabilna ${ }^{6}$. Wraz ze wzrostem profesjonalizacji wojsko zaczyna działać w sposób bardziej zorganizowany, czemu jednak nie towarzyszy proces jego odpolitycznienia, jak pisali Huntington i Rapoport. Okazuje się, iż wyższy poziom profesjonalizacji armii sprzyja jej upolitycznieniu, a oficerowie wykazują zainteresowanie sprawami publicznymi? W wielu państwach, jak np. w Egipcie, Turcji czy Algierii, słabo wyszkolone i źle zorganizowane armie, o których pisali Huntington i Rapoport,

4 D.C. Rapoport, op.cit., s. 72.

5 A. Perlmutter, The Praetorian State and the Praetorian Army: Toward a Taxonomy of CivilMilitary, „Comparative Politics” 1969, vol. 1, no. 3, s. 382-404.

6 M. Janowitz, Military Institutions and Coercion in the Developing Nations, Chicago 1977, s. 5.

7 Zob. H. Pope, N. Pope, Turkey Unveiled. New York 2004, s. 100-101; D. Lutterbeck, Arab Uprisings and Armed Forces: Between Openness and Resistance, Geneva 2011, s. 25. 
zostają zastąpione silnymi, profesjonalnymi instytucjami o wykrystalizowanych poglądach politycznych. Bardziej współcześni badacze, jak np. M. Kamrava czy S. Cook, wydają się potwierdzać te obserwacje 8 .

Pretorianizm jest zjawiskiem nie tylko złożonym, ale także podlegającym ewolucji, czego wyrazem staje się między innymi to, że w wielu państwach armie pretoriańskie nie są już wewnętrznie podzielone i tworzą spójną hierarchiczną strukturę. Stephen Cook także dostrzegł, iż współczesne profesjonalne armie, dzięki dyscyplinie, jedności i dostępowi do arsenału zbrojnego, dysponują wysokim potencjałem „szantażu politycznego”, co z kolei ma przełożenie na ich siłę względem partii politycznych ${ }^{9}$. Korpus oficerski może wywierać wpływ na decyzje polityczne bez konieczności przejmowania bezpośredniej kontroli nad aparatem państwa ruling but not governing. Armia przyjmuje więc rolę „władcy marionetek" (puppet master), zrzucając z siebie odpowiedzialność za podejmowane decyzje, którymi z kolei obarczane są elity formalnie sprawujące władzę. Skoro wojsko, dzięki swojej wewnętrznej organizacji i dostępowi do środków siłowych, ma przewagę nad instytucjami cywilnymi, rodzi się pytanie, dlaczego zjawisko pretorianizmu nie dotyka np. państw Europy Zachodniej, gdzie mamy do czynienia z najwyższym poziomem profesjonalizacji w armii. Finner w swoich badaniach podejmuje się odpowiedzi na to pytanie. Sugeruje, iż armia musi przejawiać pewne predyspozycje (profesjonalizm i spójność instytucjonalna do interwencji), ale także niezbędne jest pojawienie się określonych okoliczności, które będą sprzyjać jej upolitycznieniu. Po pierwsze, profesjonalnym armiom, które są gwarantem integralności terytorialnej państwa, będzie łatwiej przekonać opinię publiczną o konieczności ingerencji w sprawy polityczne państwa. Na przykład Izrael i Egipt, ze względu na swoje położenie geopolityczne, są zmuszone do utrzymywania wojsk w ciągłej gotowości bojowej, czego nie można powiedzieć o państwach funkcjonujących w stabilnym środowisku międzynarodowym. Brak zagrożenia zewnętrznego w państwach Ameryki Łacińskiej znacznie ograniczył polityczną rolę armii w tym regionie, co ułatwiło proces transformacji demokratycznej ${ }^{10}$. Ponadto poczucie zagrożenia zewnętrznego sprzyja profesjonalizacji armii i zwiększeniu skuteczności wywierania przez nią wpływu politycznego.

8 Zob. M. Kamrava, Military Professionalization and Civil-Military Relations in the Middle East, „Political Science Quarterly” 2000, vol. 115, no. 1, s. 69; S.A. Cook, op.cit, s. 1-13.

9 Ibidem, s. IX.

10 J. Rial, Armies and Civil Society in Latin America, [w:] Civil-Military Relations and Democracy, red. L. Diamond, M.F. Platter, London 1996, s. 51-53. 
Przykładem może być wojsko egipskie, które przeszło gruntowny proces modernizacji po przegranych walkach $z$ Izraelem ${ }^{11}$. Po drugie, ważnym czynnikiem jest poziom kultury politycznej. Zdaniem Finnera w rozwiniętych demokracjach zachodnioeuropejskich, w których społeczeństwo akceptuje istniejący porządek instytucjonalno-prawny i demokratyczne procedury alteracji władzy, będziemy mieli do czynienia z brakiem przyzwolenia na ingerowanie armii w sprawy polityczne. Inaczej jest w państwach autorytarnych czy też przechodzących proces transformacji systemowej, w których nie ma jasności co do procedur alteracji władzy, instytucje publiczne są słabo rozwinięte i społeczeństwo nie w pełni akceptuje istniejący porządek instytucjonalno-prawny.

W Turcji w latach 1960-1980 doszło do wykształcenia specyficznego kontekstu, który okazał się „katalizatorem” dla rozwoju pretorianizmu. Z jednej strony zwycięstwo frakcji umiarkowanej w armii doprowadziło nie tylko do centralizacji mechanizmów decyzyjnych, ale także dało generalicji możliwość realizowania swoich ambicji politycznych bez podejmowania ryzyka wystąpienia rozłamów w korpusie oficerskim ${ }^{12}$. $Z$ drugiej strony wzmocnienie pozycji armii nie byłoby możliwe bez sprzyjających okoliczności społeczno-politycznych. Po pierwsze, elity wojskowe odegrały kluczową rolę w walce o niepodległość Turcji, co wpłynęło znacząco na sposób postrzegania armii przez społeczeństwo. Armia od początku istnienia republiki była jednym z głównych aktorów politycznych, a zwycięscy generałowie, jak Mustafa Kemal Atatürk czy İsmet İnönü, urośli do rangi bohaterów narodowych. Wojsko tureckie nie musiało więc obalać władz cywilnych w celu zdobycia władzy. To wojsko wywalczyło niepodległość i było najważniejszym architektem, a zarazem filarem nowego państwa ${ }^{13}$. Po drugie, poczynając od roku 1960, społeczeństwo tureckie było zmęczone niestabilną sytuacją polityczną i ciągłymi konfliktami pomiędzy różnymi ugrupowaniami politycznymi. Korupcja, skandale polityczne doprowadziły do umocniona w społeczeństwie przeświadczenia, iż rządzący politycy nie potrafią skutecznie kierować państwem ${ }^{14}$. W 1960 roku, jak i w 1971 roku armia zmusiła do ustą-

11 A. Perlmutter, op.cit., s. 5-6.

12 Zob. W. Hale, The Turkish Army In Politics, 1960-1973, [w:] Turkish State, Turkish Society, red. N. Sirman A. Finkel, New York 1990, s. 65-68.

13 M. Johnson, The Role of the Military in Turkish Politics, „Air University Review” January-February 1982, s. 1. http://www.airpower.maxwell.af.mil/airchronicles/aureview/1982/jan-feb/johnson. html, odczyt z dn. 29.06.2014.

14 M.Y. Geikdaği, Political Parties in Turkey, the Role of Islam, New York 1984, s. 95. 
pienia gabinety Menderesa i Demirela, łagodząc nastroje społeczne ${ }^{15}$. Po trzecie, kontekst zimnowojenny i bliskość Związku Radzieckiego okazały się kolejnym elementem wzmacniającym pozycję armii, która stała się jedynym gwarantem suwerenności $\mathrm{kraju}^{16}$. Generałowie postanowili więc wykorzystać sprzyjające okoliczności zarówno wewnętrzne, jak i międzynarodowe w celu zwiększania swojego wpływu politycznego.

\section{INSTYTUCJONALNY WYMIAR PRETORIANIZMU TURECKIEGO}

Jak sugerowałem, współczesne armie, powinny wystrzegać się bezpośrednich form oddziaływania na struktury państwowe i starać się raczej wypracować metody kontroli pośredniej. Doświadczenia wielu państw pokazały, że armie pretoriańskie mogą to robić w dwojaki sposób:

- poprzez wykorzystanie istniejących instytucji czy też odwoływanie się do porządku prawnego;

- poprzez stosowanie szantażu politycznego, który po pewnym czasie może doprowadzić do wypracowania niesformalizowanych, jednak zrutynizowanych i pożądanych przez elity wojskowych relacji z innymi podmiotami polityki.

Większość armii pretoriańskich stara się ukryć instrumenty wpływania na elity polityczne i biurokratyczne. Wpływu tego jednak nie sposób całkowicie ukryć, bowiem reżim pretoriański musi w jakiś sposób legitymizować swoje działania, co znajduje wyraz w istniejących instytucjach politycznych, czy regulacjach prawnych. Takie osadzenie instytucjonalne umożliwia wojsku kształtowanie polityki państwa „z oddalenia”, bez konieczności „opuszczania baraków”. Warto także podkreślić, że wielość instrumentów formalnych wykorzystywanych przez armię jest uzależniona od tego, czy jest przyzwolenie społeczne do ingerowania w sprawy polityczne kraju, a także zależy od stopnia posłuszeństwa elit politycznych formalnie sprawujących władzę w państwie. W przypadku, gdy jest powszechna akceptacja zarówno ze strony społeczeństwa, jak i polityków, ilość regulacji prawnych i rozwiązań instytucjonalnych może zostać ograniczona do

15 K.H. Karpat, Military Interventions in Turkey: Army Civilian Relations in Turkey Before and After 1980, [w:] State, Democracy and the Military: Turkey in the 1980's, red. M. Heper, New York-Berlin 1988, s. 146.

16 Zob. W. Hale, Turkish Foreign Policy since 1774, New York 2003, s. 78-135. 
minimum. Jeżeli jednak takiej akceptacji nie ma, armia będzie starać się zabezpieczać swoją pozycję poprzez mnożenie bardziej zinstytucjonalizowanych narzędzi wpływu. Same zapisy instytucjonalno-prawne mogą także w dwojaki sposób zabezpieczać interesy armii. $Z$ jednej strony w aktach normatywnych może być bezpośrednie odwołanie do instytucji wojskowych, jak to jest na przykład w wypadku Wysokiej Rady Obrony (Haut Conseil de Sûreté - HCS) w Algierii. $Z$ drugiej strony przejawem zinstytucjonalizowanego wpływu są również normy prawne (też konstytucyjne), które wzmacniają pozycję armii w sposób pośredni, ograniczając swobodę działania instytucji cywilnych i społeczeństwa. Przykładowo, w Egipcie prawo 40/1977 narzuca partiom politycznym liczne regulacje, które między innymi wymagają, aby przestrzegały one zasady „demokratycznego socjalizmu” i przyczyniały się do zwiększania „bezpieczeństwa kraju”. Ponadto prawo to także zabrania zakładania partii politycznych o programie podobnym do już istniejących. Widzimy więc, że zamiast przyczyniać się do kształtowania pluralizmu w państwie, prawo 40/1977 stało się efektywnym mechanizmem kontroli politycznej, również w rękach korpusu oficerskiego ${ }^{17}$.

Kolejną metodą oddziaływania armii na politykę jest nieformalny wpływ wynikający z prestiżu, któremu często towarzyszy słabość instytucji cywilnych. W Egipcie nieformalna siła wojska opiera się na wypracowanych relacjach między personelem wojskowym a parlamentem. Przykładowo, kwestie związane z zakupem sprzętu wojskowego formalnie powinny być rozstrzygane podczas debaty na forum zgromadzenia narodowego i to do parlamentu powinno należeć ostatnie słowo. W rzeczywistości jednak minister obrony przedstawia propozycje dotyczące wyboru sprzętu i jego ilości, które nie są poddawane parlamentarnej debacie $^{18}$. Inną metodą niezinstytucjonalizowanej kontroli jest „kolonizacja” stanowisk publicznych przez armię, która staje się cechą państw pretoriańskich i dość powszechnym zjawiskiem. Wojskowi piastujący urzędy publiczne rezygnują ze swoich stanowisk w armii, pozostając jednak w dalszym ciągu jej lojalni. W Indonezji od 1997 roku emerytowani oficerowie piastowali 100 z 550 miejsc w Radzie Reprezentantów Obywateli, czyli izbie parlamentarnej (Dewan Perwakilan Rakyat - DPR) ${ }^{19}$.

17 S. Cook, op.cit., s. 69-71.

18 Ibidem, s. 74.

19 D.F. Anwar, Negotiating and Consolidating Democratic Civilian Control of the Indonesian Military, „East-West Center Occasional Papers. Politics and Security Series” 2001, s. 13, http://www. eastwestcenter.org/sites/default/files/private/PSop004.pdf, odczyt z dn. 29.06.2014. 
Omówione mechanizmy bardziej zinstytucjonalizowanego wpływu nie powstają z dnia na dzień i są zazwyczaj rezultatem długotrwałego oddziaływania elit wojskowych na system polityczny. Aby armia mogła skutecznie zakorzenić się w systemie politycznym państwa, muszą wystąpić pewne historyczne i kulturowe przesłanki sprzyjające temu procesowi. Po pierwsze, społeczeństwo musi widzieć $\mathrm{w}$ armii instytucję, która dysponuje legitymacją do ingerowania w sprawy publiczne państwa. W razie jej braku armia nie będzie w stanie sprawować efektywnej kontroli nad sferą polityki publicznej. Po drugie, wzrost poziom zaufania społecznego do armii jest wprost proporcjonalny do spadku zaufania do elit politycznych. Tylko w takiej sytuacji wojskowi są w stanie marginalizować silne partie polityczne czy też ograniczać role społecznie akceptowanych polityków. Co więcej, popularni politycy mogą podjąć próbę odcięcia się od wpływu wojskowych, a nawet starać się go skutecznie ograniczyć. W takiej sytuacji wojsko, w celu utrzymania sprzyjającego jemu status quo, zmuszone jest do wykorzystania środków siłowych, co może ograniczyć znaczenie polityczne armii. Przykładowo, Armia Egipska, która od czasów rządów Gamala Abdela Nassera cieszyła się dużym mandatem zaufania, jest w dalszym ciągu obok instytucji prezydenta głównym kreatorem polityki w państwie ${ }^{20}$. Podczas gdy w roku 2011 niechęć społeczna została skierowana tylko przeciwko niepopularnemu prezydentowi Hosni Mubarakowi, który został zmuszony do ustąpienia ze stanowiska, inaczej było dwa lata później, gdy wojsko zdecydowało się obalić w drodze przewrotu Mohameda Morsiego ${ }^{21}$. Oficerowie stanęli przed trudnym wyborem. Z jednej strony mogli pogodzić się z rządami nieprzychylnego prezydenta, który planował ograniczyć ich pozycję polityczną ${ }^{22}$. Z drugiej strony mogli podjąć zdecydowane działanie przeciwko prezydentowi, jednocześnie licząc się z opozycją ze strony społeczeństwa. Odsunięcie od władzy tego popularnego i co więcej, wybranego w pierwszych wolnych od lat wyborach prezydenta znacznie nadszarpnęło

20 I. Harb, The Egyptian Military in Politics: Disengagement or Accommodation?, „Middle East Journal” 2003, vol. 57, no. 2, s. 269-290; D. Kutzer, M. Svenstrup, Egypt's Entrenched Military, „The National Interest" 2012, http://nationalinterest.org/article/egypts-entrenched-military-7343, odczyt z dn.2 9.06.2014; D. Brumberg, S. Sallam. The Politics of Security Sector Reform in Egypt, „Special Report 318” 2012, United States Institute of Peace, http://www.usip.org/sites/default/files/SR318_0. pdf, odczyt z dn. 29.06.2014.

21 T. Tudoroiu, Assessing Middle Eastern Trajectories: Egypt after Mubarak, „Contemporary Politics" 2011, vol. 17, no. 4, s. 378-381.

22 T. Özhan, New Egypt versus the Felool: Struggle for Democracy, „Insight Turkey” 2013, vol. 15, nr 1, s. 13-23. 
wizerunek i pozycję armii w państwie. Przewrót wojskowy albo groźba jego przeprowadzenia, mimo tego, że jest ostatecznością także, pozostaje jednym z głównych instrumentów działania armii pretoriańskich, podejmowanych w sytuacji, gdy wszystkie inne środki zawodzą ${ }^{23}$.

W historii Turcji mamy do czynienia z trzema przewrotami wojskowymi, w latach 1960, 1971, 1980, oraz z tak zwanym przewrotem postmodernistycznym w 1997 roku, w którym armia jednak nie przejęła sterów władzy. Podczas gdy pierwsze dwa przewroty były w dużej mierze podyktowane presją wewnątrz armii, która nie miała jeszcze wyklarowanej wizji rządzenia państwem, to przewrót w 1981 roku był zaplanowaną operacją wojskową. Dowodem na to jest fakt, że powstały wyspecjalizowane struktury wojskowe, które już wiele lat wcześniej zaczęły zajmować się przygotowywaniem planów działania ${ }^{24}$. W roku 1960 oraz w 1971 armia, nie mając jeszcze wizji co do metod wpływania na politykę państwa, często improwizowała i była pod wpływem polityków, w szczególności z Partii Republikańskiej (Cumhuriyet Halk Partisi, CHP). Po roku 1960, mimo tego, że wojsko mogło w sposób bardziej gruntowny wpłynąć na strukturę państwa, junta wojskowa bardziej skupiła się na metodach zastraszenia polityków, a nie na wypracowywaniu zinstytucjonalizowanych form nacisku. Co ciekawe, konstytucja stworzona przez Komisję Onara ${ }^{25}$, która zakończyła prace w 1961 roku i pracowała pod nadzorem armii, przygotowała dla Turcji bardzo demokratyczne rozwiązania, m.in. gwarantując podstawowe prawa i wolności człowieka $^{26}$. Najważniejszą formą kontroli, co umożliwiało korpusowi wpływ polityczny, była ustanowiona na mocy art. 111. Narodowa Rada Bezpieczeństwa (Milli Güvenlik Kurulu, MGK). Miała ona konsultować z Radą Ministrów najważniejsze decyzje związane $\mathrm{z}$ bezpieczeństwem narodowym ${ }^{27}$. Drugi przewrót wojskowy, znany jako memorandum z 12 marca 1971 roku, także nie wpłynął znacząco na zmianę porządku politycznego, a tym bardziej nie pojawiły się próby dalszej instytucjonalizacji roli armii w polityce. Wzmocniono co prawda rolę Narodowej Rady Bezpieczeństwa przez wprowadzenie poprawki do art. 111/3, stitution-text.pdf, odczyt z dn. 29.06.2014.

27 Ibidem, art. 111. 
na mocy której „zalecano”, aby Rada Ministrów brała pod uwagę opinie armii, co zwiększyło tym samym znaczenie tej instytucji ${ }^{28}$.

Po roku 1973 generalicja doszła do wniosku, że w celu sprawowania skutecznej kontroli konieczne będą bardziej radykalne zmiany, zmierzające do ograniczenia roli elity politycznej (priorytet interesu narodowego nad partykularnymi interesami grup społecznych), a przede wszystkim ugrupowań radykalnych (m.in. komunistów). Co ciekawe, trudności gospodarcze i niestabilność polityczna państwa spowodowały, że armia, przejmując władzę, miała nie tylko poparcie generałów i oficerów, ale także społeczeństwa. Tanel Demirel, podczas wywiadu z głównodowodzącym armii generałem Kenanem Evrenem, na pytanie, czy armia spodziewała się oporu podczas swojej operacji ze strony różnych grup społecznych, uzyskał odpowiedź, że dowództwo było w dziewięćdziesięciu procentach pewne swojego działania ${ }^{29}$. Rzeczywiście wiele źródeł potwierdza, że sam przewrót 1980 roku był dopracowany w niemal każdym szczególe i to, że Hugh i Nicole Pope nazwali go „przewrotem w białych rękawiczkach”, w żadnym wypadku nie odbiega od prawdy ${ }^{30}$. Jednak proces „dojrzewania” armii miał bardzo daleko idące konsekwencje dla przyszłości państwa, a konstytucja z 1982 roku jest tego widocznym objawem. Można więc przyjąć, iż dokument ten, będący rezultatem ścierania się różnorodnych interesów (nie tylko wojska), zapewnił armii kontrolę, nad życiem publicznym, jak i politycznym państwa.

Rola wojska jako gwaranta porządku kemalistycznego nie znajduje bezpośredniego umocowania w konstytucji z 1982 roku. Jak wspomniałem, wojsko zaczęło postrzegać swoją rolę (zwłaszcza od końca lat siedemdziesiątych XX wieku) jako gwaranta interesu narodowego i kemalistycznych reform. Ta samodzielnie wykreowana przez wojsko rola została dodatkowo wzmocniona i poszerzona przez koncepcję narodowego bezpieczeństwa, a tak naprawdę bezpieczeństwa państwa. Jest tak dlatego, iż zasadniczą wartością dla elity kemalistycznej jest przetrwanie nie tyle społeczeństwa co państwa.W tej sytuacji należy więc z jednej strony zwrócić uwagę na postanowienia konstytucji, a z drugiej - na regulacje prawne (kodeksy) dotyczące funkcjonowania Sił Zbrojnych, które tworzą prawne podstawy do określenia ich roli w polityce. Spróbujmy więc spojrzeć na konstytucyjny kontekst racjonalizacji swej roli przez TSK i na przepisy rangi

28 I. Uzgel, Between Praetorianism and Democracy; the Role of the Military in Turkish Foreign Policy, http://dergiler.ankara.edu.tr/dergiler/44/674/8590.pdf, odczyt z dn. 29.06.2014.

29 T. Demirel, The Turkish Military's Decision to Intervene 12 September 1980, „Armed Forces and Society" 2003, vol. 29, no. 2, s. 269.

30 H. Pope, N. Pope, op.cit., s. 141. 
niekonstytucyjnej, na które siły zbrojne często powołują się i traktują je jako podstawę prawną wielu decyzji czy też przedsięwzięć, również o politycznym charakterze. W pierwszej części konstytucji - zasady ogólne - znajdujemy art. 1, deklarujący, iż państwo tureckie jest republiką, oraz art. 2, stanowiący, iż „Republika Turcji jest demokratycznym, świeckim i socjalnym państwem opartym na rządach prawa; kierującym się koncepcjami publicznego pojednania, narodowej solidarności i sprawiedliwości; respektującym prawa człowieka; lojalnym wobec nacjonalizmu Ataturka i opartym na fundamentalnych zasadach sformułowanych w Preambule" 31 . W art. 3 mowa jest o niepodzielności zarówno terytorium, jak i narodu. Co ciekawe, według art. 4, artykuły 1, 2 i 3 nie mogą zostać zmienione i nie może zostać sformułowana propozycja ich zmiany ${ }^{32}$. Przepisy konstytucji wprowadzają więc trzy podstawowe wartości, których ma bronić armia i szerzej - elita kemalistyczna. Po pierwsze, chodzi o niepodzielność zarówno terytorium, jak i narodu, po drugie - uszanowanie zasad kemalizmu, po trzecie - świecki charakter państwa (sekularyzm) oraz po czwarte - republikańską formę państwa. Jak już sugerowałem, nie znajdujemy w tych przepisach konstytucyjnych bezpośredniego odwołania do roli armii. Oczywiście to, co tak naprawdę może zagrażać szeroko pojętemu „narodowemu interesowi”, nie jest uściślone w konstytucji, i to właśnie te ogólne zasady umożliwiają wprowadzenie bardzo „swobodnej” interpretacji prawa. Druga i trzecia część konstytucji, Prawa i obowiązki obywatelskie oraz Organy Republiki Tureckiej, do złudzenia przypominające artykuły o podobnej treści zapisane w konstytucjach rozwiniętych państw demokratycznych, z uwagi na swoją strukturę mogą zmylić nieuważnego czytelnika. Przykładowo, na podstawie art. 17, 18 czy 20 można rzeczywiście przyjąć, iż obywatel dysponuje takimi samymi prawami co Europejczyk, co więcej, porządek instytucjonalny i zasada trójpodziału władzy i prawa polityczne wydają się „skrojone” na podobieństwo konstytucji demokratycznych (część III konstytucji, art. 75-160). Jeżeli jednak dokładniej przyjrzymy się poszczególnym zapisom, to nietrudno dostrzec, że poszczególnym przepisom prawnym „przypisane” są krótkie komentarze czy też odwołania do innych artykułów, które wpływają na sposób interpretacji tekstu konstytucji. Przykładowo, art. 24 stanowi, że każdemu zapewnia się wolność sumienia i religii. Dalej w tym samym artykule czytamy, że „wolność sumienia i religii może zostać ograniczona, jeżeli

31 Konstytucja Turcji z 1982 r., Preambuła, http://www.refworld.org/cgi-bin/texis/vtx/rwmain?docid=3ae6b5be0, odczyt $\mathrm{z}$ dn. 29.06.2014.

32 Ibidem, art. 4. 
nastąpi naruszenie niepodzielności terytorium państwa i narodu, pogwałcenie fundamentalnych zasad funkcjonowania państwa [...]"33. Co ciekawe, jak wspomniałem, armia zabezpieczyła także swoje interesy przez wykorzystanie art. 4, na mocy którego wymienione już artykuły 2 i 3 pod żadnym pozorem nie mogły zostać zmienione przez parlament ${ }^{34}$.

Po przewrocie wojskowym w 1980 roku konstytucyjnego wzmocnienia doczekała się także Narodowej Rady Bezpieczeństwa (MGK), w której liczba cywilnych członków została zredukowana do pięciu (zasiadało w niej również pięciu reprezentantów TSK), a zmiana w konstytucji zobowiązywała władze cywilne do traktowania rekomendacji jako priorytetowych. Art. 118 konstytucji z 1982 roku przewidywał, iż MGK „może przedstawić Radzie Ministrów swoje rekomendacje dotyczące wewnętrznego i zewnętrznego bezpieczeństwa kraju”. W tym samym artykule znajdujemy passus, że Rada Ministrów daje priorytet rekomendacjom MGK dotyczącym przewidywanych przez nią środków, traktowanych jako konieczne dla ochrony „istnienia i niepodległości państwa, integralności i niepodzielności kraju, pokoju i bezpieczeństwa kraju”. W istocie rzeczy oznaczało to, iż Rada Ministrów przyjmowała rekomendacje jako wiążące i uwzględniała je w projektach rozstrzygnięć prawnych.

Zapisy konstytucji okazały się skutecznie bronić interesów armii i doprowadziły do ustąpienia ze stanowiska premiera Necmettin Erbakana i zakończenia rządów nieprzychylnej armii Islamskiej Partii Dobrobytu (Refah Partisi - RP, 1996-1997). Ustawa zasadnicza, a dokładniej art. 68 stanowiący, że „obywatele mają prawo zakładać partie polityczne tylko wtedy, gdy jest to zgodne z funkcjonującymi procedurami [...] określonymi przez konstytucję i prawo [...]" okazał się głównym orężem walki politycznej w rękach armii ${ }^{35}$. W walce przeciwko Erbakanowi oprócz zapisów konstytucyjnych wykorzystano także artykuły 78-97 Prawa o partiach politycznych, w których można przeczytać, że partie nie mogą być organizowane na zasadach, „sekciarskich, religijnych czy rasowych, czy też w innych formach mobilizacji społecznej godzących w interesy państwa [...]"36. Obok Prawa o partiach politycznych armia w walce politycznej wykorzystywała nieraz inne dokumenty, jak Kodeks karny, Kodeks cywilny, Prawo

\footnotetext{
33 Ibidem, art. 14, 24.

34 Ibidem, art. 4.

35 Ibidem, art. 68.

36 E. Yylmaz, Sociology of Political Parties' Closure Regime, „African Journal of Business Management" 2009, vol. 3, no. 12, s. 832 .
} 
antyterrorystyczne z 12 kwietnia 1991 roku czy Dokument narodowej polityki bezpieczeństwa. Wszystkie te dokumenty mają oparcie w ustawie zasadniczej z roku 1982 i tak naprawdę służą jako jej „dopełnienie” ${ }^{37}$.

Innym ważnym dokumentem, o którym także wspomina konstytucja $\mathrm{z}$ roku 1983, jest Dokument narodowej polityki bezpieczeństwa (Milli Güvenlik Siyaseti Belgesi - MGSB). Właśnie w tym dokumencie, który podlega rewizji co pięć lat, zawarte są cele strategiczne korpusu oficerskiego przez definiowanie zarówno wewnętrznych, jak i zewnętrznych zagrożeń. Przykładowo, w roku 1992 w MGSB w dalszym ciągu za największe zagrożenie zewnętrzne uznano niestabilną sytuację w byłych republikach radzieckich, natomiast fundamentalizm islamski i separatyzm kurdyjski zostały zidentyfikowane jako zjawiska zagrażające bezpieczeństwu wewnętrznemu ${ }^{38}$.

Należy więc zauważyć, iż prawo w Turcji zawiera szereg regulacji konstytucyjnych i pozakonstytucyjnych, które przekazują wojsku pakiet kompetencji dotyczących natury państwa, warto dodać, państwa interpretowanego poprzez pryzmat ideologii kemalistycznej. Co istotne, te kompetencje - jak zauważa F. Misrahi - „dotyczą roli TSK w sferze bezpieczeństwa wewnętrznego, włączając w to wywiad, oraz misję związaną z ochroną natury kemalistycznego rezimu" ${ }^{39}$. Zwłaszcza art. 85 i 35 ujawniły swą przydatność w działaniach wojska. Ich bardzo ogólnikowe brzmienie w zasadzie uzasadnia każdą interwencję wojska w politykę wewnętrzną Turcji poprzez użycie nieformalnych mechanizmów, które mają służyć np. ochronie porządku sekularnego (zagrożenie - islamizm) czy też spójności terytorialnej państwa (zagrożenie - separatyzm kurdyjski).

Uwagę mogą przyciągnąć kompetencje, jakimi zostały obdarzone trybunały i sądy wojskowe. Na mocy art. 141 mogły w szczególnych sytuacjach, jeżeli dotykały one ważnych kwestii dotyczących bezpieczeństwa państwa, przejmować kompetencje sądów cywilnych. Dalej, ważnym ograniczeniem praw i wolności obywatelskich jest zapis art. 141, mówiący o tym, że obowiązkiem sędziów jest przeprowadzanie rozpraw sądowych w trybie natychmiastowym i przy jak najmniejszym nakładzie środków" ${ }^{40}$. Art. 141 nieraz był wykorzystany w spra-

37 Prawo anty-terrorystyczne, Act. No. 3713, „Official Gazette” 1991, art. 1, http://www.opbw.org/ nat_imp/leg_reg/turkey/anti-terror.pdf, odczyt z dn. 29.06.2014.

38 G. Jenkins, Context and Circumstances: The Turkish Military and Politics, New York 2001, s. 48.

39 F. Misrahi, The EU and the Civil Democratic Control of Armed Forces: An Analysis of Recent Developments in Turkey, „Perspectives” 2004, vol. 22, s. 31.

40 Konstytucja Turcji, op.cit., art. 141. 
wach „delikatnych”, które były rozwiązywane bez rozgłosu, dotyczących kwestii kurdyjskiej czy też opozycji islamistycznej.

Obok ograniczenia wolności obywatelskich, specjalnych uprawnień dla trybunałów wojskowych w konstytucji znalazły się także normy wzmacniające istniejące inne organy państwowe będące pod kontrolą armii. Prezydenta Republiki Tureckiej, na mocy nieformalnej umowy pomiędzy elitami wojskowymi i politykami (od początku lat osiemdziesiątych), wyłaniali parlamentarzyści, jednak spośród osób lojalnych wobec armii. W związku z powyższym konstytucja z roku 1983 znacznie zwiększyła prerogatywy prezydenckie. Na mocy art. 104 prezydent decyduje o obsadzeniu najważniejszych stanowisk w instytucjach publicznych w państwie, do których należą m.in. stanowiska: głównodowodzącego Armii Tureckiej, członków Narodowej Rady Nadzorczej, Członków Najwyższej Rady Edukacyjnej, rektorów Uniwersyteckich, członków Trybunału Konstytucyjnego. Prezydent także „Zwołuje posiedzenia Narodowej Rady Bezpieczeństwa, której także jest przewodniczącym, może wprowadzać godzinę policyjną i ogłaszać stany wyjątkowe w państwie" ${ }^{41}$. Widzimy więc, że ugrupowanie polityczne czy instytucja, która odpowiada za nominację głowy państwa, mają ogromny wpływ na sytuację polityczną w kraju dzięki możliwości obsadzania najważniejszych stanowisk w sądownictwie i edukacji.

\section{PODSUMOWANIE}

Turcja jest przykładem państwa, w którym armia jest częścią systemu politycznego, co znajduje odzwierciedlenie nie tylko w porządku instytucjonalno-prawnym, ale także, co ważniejsze, jest rezultatem długotrwałych procesów historycznych i kulturowych. Formy zinstytucjonalizowanego wpływu politycznego i mechanizmy (nieformalne) wywierania nacisku na system polityczny, o których mowa była wcześniej, przenikają się wzajemnie. W walce z premierem Erbakanem orężem walki politycznej stały się art. 68 konstytucji i zapisy art. 78-97 ustawy o partiach politycznych. Praktyka turecka ukazała więc, że niesformalizowane instrumenty wpływu politycznego określają pozycję armii, jednak to zapisy konstytucyjne i inne akty prawne służą jako ważny instrument legitymizujący jej działania. Wspomniane instrumenty prawne na nic by się zdały, gdyby TSK

41 Ibidem, art. 104. 
nie otrzymała przyzwolenia do działania od społeczeństwa, wynikającego ze specyficznych uwarunkowań historycznych i społecznych.

Islamska Partia Sprawiedliwości i Rozwoju od czasu wyborów w 2002 roku jest dominującą siłą polityczną w parlamencie tureckim i może poszczycić się sukcesami w walce $\mathrm{z}$ TSK, co znajduje odzwierciedlenie między innymi w zmianach konstytucyjnych, jakie zostały wprowadzone na przestrzeni ostatnich lat ${ }^{42}$. Można więc stwierdzić, że dzięki działaniom partii premiera Erdoğana i dzięki reformom mającym na celu harmonizację prawa tureckiego z prawem unijnym, pod względem instytucjonalnym, pozycja armii w Turcji została znacznie osłabiona. Pojawia się jednak pytanie: czy w obliczu pogłębiającego się kryzysu politycznego w Turcji oraz ewentualnego spadku popularności partii rządzącej społeczeństwo tureckie nie zwróci się ponownie w kierunku armii tureckiej jako gwaranta reżimu kemalistycznego?

42 Z. Sarigil, The Turkish Military, Principal or Agent, „Armed Forces \& Society” 2014, vol. 40, no. 1 , s. $178-180$. 